\title{
PARTICIPATION OF LEADERS AND COMMUNITY IN SOLID WASTE MANAGEMENT IN INDONESIA TO REDUCE LANDFILL WASTE LOAD
}

\author{
Indriyani Rachman $^{1,2, *}$, Qiyam Maulana Binu Soesanto ${ }^{1}$, Hafizhul Khair ${ }^{3}$, Toru Matsumoto ${ }^{1}$ \\ ${ }^{1)}$ Faculty of Environmental Engineering, the University of Kitakyushu, Japan \\ ${ }^{2)}$ Postgraduate Science Education, Pakuan University Bogor, Indonesia \\ ${ }^{3)}$ Faculty of Engineering, Universitas Sumatera Utara, Indonesia
}

\begin{abstract}
The increase in population and changes in community consumption patterns are one of the triggers for the increasing volume of waste. Therefore, changes are needed to manage waste so that the accumulation of waste can be handled properly. Government cooperation is considered important in solving problems. The volume of waste from its source has to be reduced. Therefore, it is important to empower the community in managing waste. This study compares the community participation in 3 villages in managing waste in their respective housing areas and waste management managed by the City Sanitation Department. Waste management in 3 locations became areas that can reduce the amount of waste going to the landfill. The data collection methods include interviews, observation and documentation, while data analysis uses descriptive qualitative techniques. Based on the results of the study, one form of leader and community participation in environmental improvement efforts is by participating in managing waste, participating in 3R workshops and giving labor contributions in the form of community service.
\end{abstract}

Keywords: community participation, solid waste management

\section{Introduction}

The most universal problem affecting everyone in the world is problem of solid waste. Individuals and government must be involved in making decisions about consumption and waste management because it can affect the health, productivity, and cleanliness of the community. It said that, region in East Asia and Pacific Place, most common waste is plastic waste with $53.1 \%$, second common waste is paper and cardboard. Waste disposal and treatment in East Asia and pacific is landfill (unspecified) is $45.6 \%$, and no two is incineration, composting is about $0.01 \%$. In Indonesia, waste disposal and

${ }^{*}$ Corresponding Author:

E-mail: rachmanindriyani@gmail.com

Received: 18 May 2020

Revised : 13 August 2020

Accepted: 7 September 2020 treatment is final disposal-open dumping, in Indonesia there are around 460 landfill areas (Kardono, 2008).

Most capital cities in Indonesia have not fully implemented the government regulatory mandate UU No. 18/2008, about solid waste management. UU No. 18/2008 changes the paradigm from waste disposal to waste recycling. UU No. 18/2008 controls that MSW (Management of Solid Waste) must be managed with reduction and handling. Reduction includes minimization of solid waste generation, recycling, and reuse. Handling includes waste separation, collection, transportation, processing, and land filling (Abdel-Shafy et.al, 2018).

In general, there are three types of recycling activities in Indonesia, recycling by the informal sector including scavengers; recycling dealers; and recycling the industry, composting activities 
at SW small processing facilities and solid waste banks by the community (Rachman et al., 2017). Community gives a significant influence inSWM program performance (Rijayanti et.a, 2020).

The rapid rate of population growth has resulted in increased waste generation. Therefore, it is necessary to formulate an effective waste management model so that the load of waste entering the landfill does not get heavier. There have been many efforts to manage solid waste by the government, community organizations and community self-sufficiency, especially those based on the 3R management concept (Raharjo et.al, 2017a, Yustiani et.al, 2019). The 3R program for solid waste can also in return be applied to mitigate greenhouse gases (Raharjo et.al, 2017b.). This study aims to compare the waste management model recommended by the government and community-based waste management, especially in residential areas in Indonesia. The comparisons made are expected to show the most suitable waste management model to be applied in big cities in Indonesia.

\section{Research Methodology}

This research uses descriptive quantitative research method, which aims to describe, explain and validate social phenomena as research subjects. The descriptive research method requires two elements of research, namely the tools or data collectors and the data sources or patterns from which the information will be extracted. The methods used to collect data were interviews and field observations.

Types of data collected include regional waste management flows, and conditions and public opinion. There were 3 groups of respondents whose data were taken, namely the Rewin community, the Kampung Tin community, and a pilot model for waste management belonging to the Surabaya city sanitation department. Respondents selected came from the community and local government.
In qualitative research, interviews and participatory observation are used as data collection tools, therefore this research analysis is provided in the form of text or textual discourse, including qualitative studies used by discourse analysts as an investigative method. The results of the interview data were mapped using the flow and description flow.

\section{Results and Discussion}

\section{Existing Waste Management}

1. Rewin Village

Rewin Village is located in Sidoarjo City which is adjacent to Surabaya City, the capital of East Java Province. Sidoarjo City has many waste banks operated by housing groups. One of these waste banks is located in the Rewin housing estate. This housing area has an area of approximately $150 \mathrm{~m}^{2}$. The local community started the operation of this waste bank by holding discussions on independent waste management as support for government programs. The head of the resident group of Rewin housing conveyed his proposal in the form of a clean environment program, which began with planting 2 trees in front of each house. In addition, a park is also planted with trees so that the air is cleaner. After this program is successful, it is followed by a waste bank operation program.

To initiate the operation of the waste bank, Kampung Rewin held training first. The things taught in this training include how to sort waste, especially to provide an understanding of what waste can be sold to a waste bank. The waste bank program was successfully implemented and followed by several surrounding houses. Non-organic waste is sold by the community to waste banks, while organic waste is composted in a special composting place.

This program at Kampung Rewin Housing can represent other areas that carry out communitybased independent waste management. The flow of waste arising in this residential area can be 
seen in Figure 1. The waste generated from each house is divided into 2 types, namely organic and non-organic. The organic waste is examined by the group leader, then taken by a tricycle to the compost house. The compost produced is returned to residents who need it. Meanwhile, non-organic waste is divided into 2 types, namely those with recycled value and those that cannot be recycled. The last type of waste is categorized as residue which is carried to landfill. Meanwhile, recyclable waste is collected at the area head's house. This waste is partially recycled independently into crafts. Some, such as paper, cardboard, iron, aluminum, are sold to recycling factories.

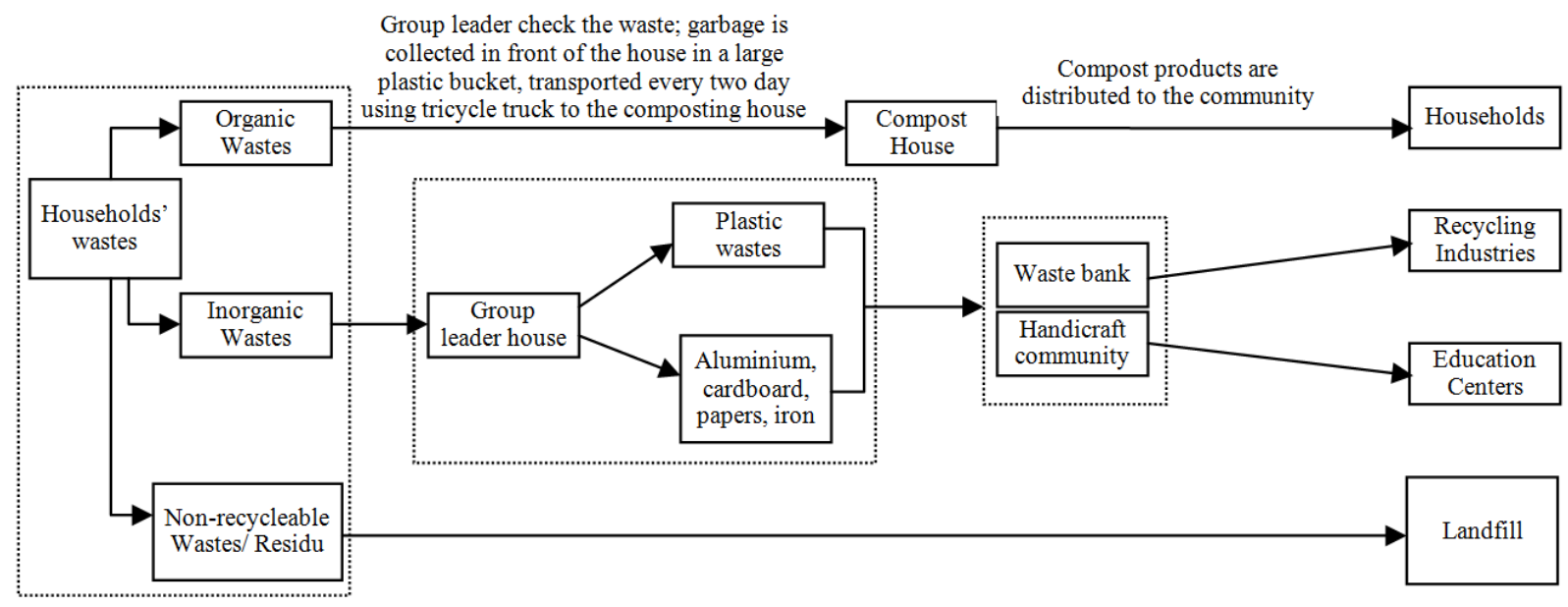

Fig.1. Flow of solidwaste in the Rewin Village.

\section{Tin Village}

This area is named the Tin Village because it uses figs as theme and source of income for the community. Tin is figs in Indonesian Language. In this village, the garbage from the house is divided into 3 methods, to the waste bank or sold to flea market, organic waste into biopori to compost to grow figs/tin or for garden site and residu of waste is transported by municipal cleaners to landfild site. Biopori is a composting method that organic wastes are put in $1 \mathrm{~m}$ deep cylindric hole. The average waste generation from each house is around 1-5 kg per day which $30 \%$ of it is inorganic waste.

One of the head of household in Tin Village had a great effort to empower the community. This leader has a figs leaves tea business that one day he cannot cover market demand. Thus, he and the other group leaders invite all residents in RT 08 to plant figs trees in large pots to cover market demand. This idea was welcomed by all residents. The head of the group as the leader in Tin Village, educates his people to be able to maintain figs trees. Leaders also did not get bored of walking around to meet every citizen and listening to his citizens' complaints regarding the Tin tree. Every Saturday, Sunday, when he was off from work, the leader made a small group talk at nearby park. It takes 3 years to learn the process of caring for figs trees until they can harvest mature leaves and bear fruit. The role of the leader is very influential, because not a few residents are almost desperate because their figs plants do not grow properly. With painstaking and continuous efforts, the residents of Tin Village were able to produce the figs fruit and snacks to meet market demand. Also, figs leaves are processed into tea, packaged, then sold to the market or through online sales. There are also some resellers who immediately come to buy figs tea that is ready to use without being packaged. To fulfill the figs tree fertilizer, the 
residents are mobilized to make compost using biopori from the domestic waste of each house. Every 6 houses has one biopori hole, then the compost is used to fertilize figs plants and plants in the small garden, group garden, this garden is also a playing facility for children and adults to exercise or to sit and sit and chat. Then all residents take care of the tree and get funds from the business. This becomes additional income for the residents as well. In addition, inorganic waste is put into the waste bank which can be deposited every Monday and Thursday, and the results of this waste deposit become savings for residents as members of the waste bank. There are 2 types of savings, namely residents depositing rubbish, then converting it with savings, residents can also borrow money and then pay by depositing valuable waste. The residual waste is transported by the municipal sanitation office. Residents pay a monthly retribution for garbage transportation of IDR 15,000 .

Apart from figs leave tea, there is also a cake production house and souvenirs from Tin Village, which is in the form of cakes and jams made from figs fruit. This activity is an additional income.

Kampung Tin is a model village doing business by managing and utilizing waste. After this village of Tin developed, it became famous in the city of Malang, now there are always visits from residents of other villages, who want to learn about the maintenance of figs plants, making tea and cakes from figs fruit. In this case, the residents become agents of change in environmental maintenance.

In Kampung Tin, the remaining residual waste that is disposed of in the landfild is around 20$30 \%$ of the amount of household waste, usually leaves and tree branches and wood, plastic type that does not sell in cans in garbage banks, broken glass and plates, cloth and used clothes. For clear and colored glass bottles, they are usually sold to junk dealers or given to scavengers. The flow of solid waste management in Tin Village is shown in Fig.2.

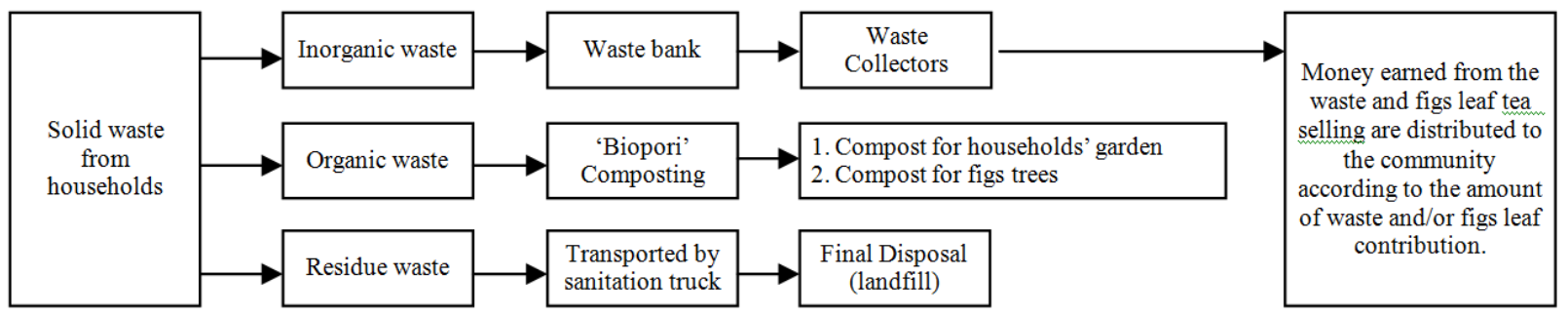

Fig. 2. Flow of solid waste management in Tin Village.

3. Recycling Center of Jambangan Depot (PDU) Surabaya

Built since 2016 by the Ministry of Environment and Forestry with the aim of being one of the efforts of the Surabaya City Government, to reduce the supply of waste to landfills, the Jambangan Recycling Center is under the responsibility of the Surabaya local government as part of the sanitation department and city landscaping. PDU Jambangan continues to actively manage waste from all residents in
Jambangan Village. The area of Jambangan Village is $77,764 \mathrm{~m} 2$ with a population of 8708 people. PDU Jambangan stands on an area of approximately 2,910 square meters, with a warehouse building measuring $20 \times 15$ square meters. PDU Jambangan can manage around 5-6 tons of waste per day. The Jambangan recycling center receives 30 waste carts every day, with cart sizes $120 \mathrm{~cm}$ long, $60 \mathrm{~cm}$ wide, $100 \mathrm{~cm}$ high. The waste is household domestic waste from the Jambangan village, which contains 
various types of waste, namely, organic, inorganic to plastic waste. After receiving the waste from the cart, the officers sort plastic, cardboard, refills and waste which are the raw materials for composting. Before processing, the collected wastes are first sorted, to separate organic and inorganic waste, such as colored plastic, transparent plastic, paper, plastic bottles and cans. Inorganic wastes have money value, while organic waste can be processed into fertilizer.

Especially for plastic waste, the officers manage it well by separating plastic waste from other waste then pressing it in a box container so that it becomes a solid box. Then this plastic waste is deposited to collectors of waste to be sold and recycled at the factory, the proceeds from the sale of this plastic waste are distributed equally to the salaries of honorary workers, amounting to 15 inorganic parts, 7 compost people and 3 technicians, purchasing water. Drink and lunch for the workers at the TPS. The average amount of plastic waste is around 15\% of the waste brought to the TPS. This type of waste is the cardboard, glass, broken glass, plastic bottles, plastic bags. The garbage collected is organic and inorganic waste. This inorganic waste is in the form of duplex paper, food boxes, HVS paper, plastic bottles, used bottles, glass bottles, sandals, plastic sachets etc. For organic waste, it is processed into organic compost for fertilizing city parks. Surabaya residents can also get it for free, simply by showing their identity card (KTP). Meanwhile, residual waste in the form of pads and diapers is immediately disposed of in the TPA.

For organic waste is composted and inorganic sold to collectors. From the sale of inorganic waste, is used to pay the salaries of temporary workers. Then the waste residue is disposed of in a landfill. below, picture $X$, is a description of the flow of garbage from the house to the neighborhood, then to a temporary disposal site, sorted and disposed of at the final disposal site.

PDU Jambangan is often the destination of a number of guests from outside the city. Jambangan, known for the success of its citizens in managing waste or recycling. This made Jambangan, a pilot area. A number of activists from various communities visited PDU Jambangan, to see directly the waste management process. Explained some of the activities there, one of which is the management of organic waste which is processed by the composting method whose raw materials come from arganic waste from the residents of the Jambangan village and dry leaf litter from the city park, which is deposited by the gardening office. The head of the PDU office plays a role in explaining all activities to visitors who want to learn about waste management.

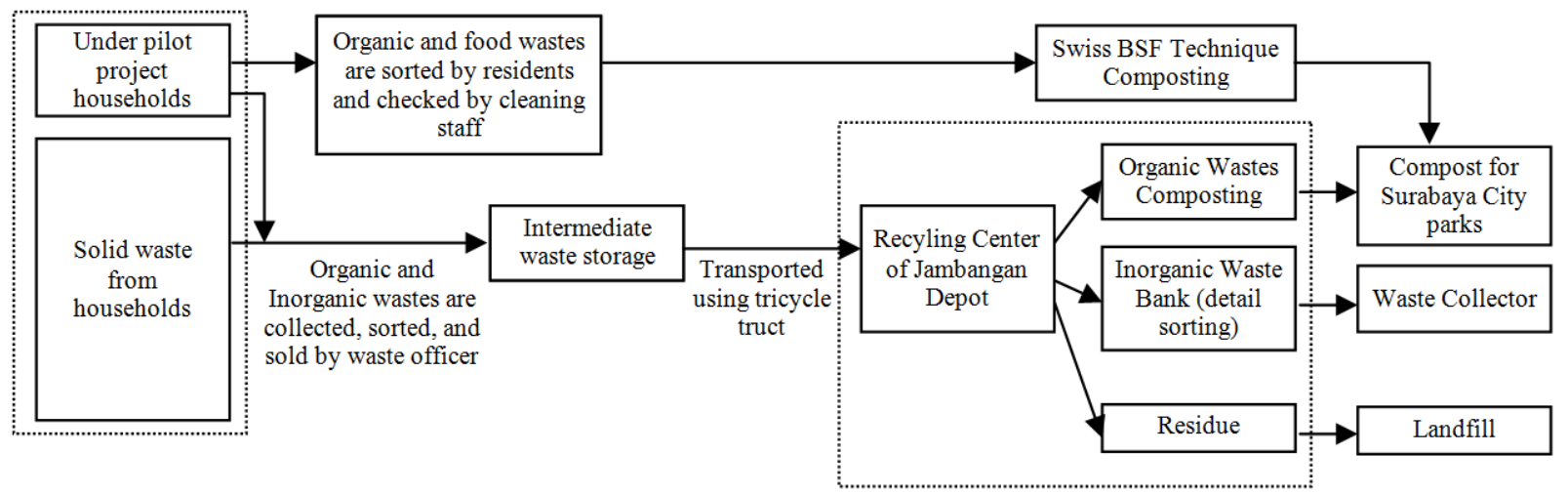

Fig. 3. Flow of solid waste management in Recycling Center of Jambangan Depot. 


\section{Analysis}

\section{Waste Bank Activity}

Waste bank, can be also referred as trash bank, is a place to recycle and/ or collect waste that can still be used (Solihin, 2018; Yustiani et.al, 2019).

The developments of waste banks are started from sub-district (RW). Initiated by the head of the RW, a waste bank was formed that received inorganic waste from households, in the form of plastic, plastic bottles, newspapers and cardboard. After one year the development of the waste bank has become very rapid. The complex garden used as a place to collect goods. Then make compos fertilizer from organic waste in RW 13. Composting can also be applied individually to reduce organic waste from its sources (Bonoli et.al, 2019; Hartono, et.al, 2015; Pan et.al, 2012).

The sanitation section continues to invite residents to participate in waste management; RW conducts training, counseling and direct guidance to local residents on the day of garbage disposal and transportation. If the garbage is still mixed, the garbage officer is not willing to transport the garbage. Strict regulation will lead to good habits in solid waste management (Nizar et.al, 2018). The RW has managed to manage its waste so that only residual waste is dumped into the landfill using the truck owned by the chairman of the RW. For truck and staff operations fee citizens have to pay IDR 12,000.

Starting from the year of 2014, this waste bank has been developed, so that it produced as many waste bank subsidiaries spread across several sub-district. The turnover of the waste bank, which was 13 , became 21 , within the 5years period. The number of waste bank members has also increased. Also greening of plants program in RW makes shady environment and clean air. Eventyally, due the all of the residents hardwork for growing plant and using compost. Composting can elevate the solid waste handling
(Hasbiah et.al, 2018) and give an indirect profit of waste bank.

Changes in the residential area are also very intense, from what used to be a lot of garbage in the collection until free from a lot of waste. But it is still felt by the cleaning service employee.

From the results of interviews with the RW cleaners, they still felt the lack of full community participation, it was seen that there were still residents who did not sorting out their rubbish, to depositing their rubbish into the waste bank even though the location was close, and there were residents who dumped their rubbish into another RW, because in several other RWs are not required to separate waste, because the garbage is directly transported to the landfill site. There is an opinion that residents have already paid waste fees, so why should they sort them out and reduce waste. Continuous refreshment and encouragement trainings are needed in keeping the sustainable program (Fredrick et.al, 2018; Yoada et.al, 2014).

The purpose of the cleaning committee in RW 13 is actually inviting residents to care about the environment, inviting residents to manage their own waste in accordance with government regulation of the republic of Indonesia no. $81 / 2012$ concerning management of household waste and waste type of household waste. Then the RW chairman with their own money invited the residents to live environmentally friendly. But there are still big obstacles to invite residents who have not participated in waste management.

This research wants to find the cause of the existence of residents who are not yet willing to join and take responsibility for the waste they have caused. In addition, if RW 13 can solve this problem, it is hoped that it will become a model of a small community in managing its own waste, so that the reduced amount of waste dumped in the landfill. Surely it will be related to extending the life of the landfill in Sidoarjo. 
Analysis of waste management activities carried out by the community at RW (Citizens Association) 13 Rewin, initiated by the RW management, RW 13 consists of 17 RTs. Each RT (Neighborhood Association) has about 35-40 households. Where in one RT consists of the chairman of the RT, deputy, secretary, treasury and person in charge of environmental. The task of the person in charge for the environment is to monitor the condition of the garbage that comes out of the household, provide counseling to its citizens related to waste and invite its citizens to participate in waste management. The collaboration between residents and management in the Rewin Village environment is one of the factors that supports the success of the Rewin Village to become a clean area without waste and residue. This complex does not rely on government intervention in managing its waste. This could be an example for housings. Residents sort waste, inorganic rubbish in tubes in garbage banks, organic waste is sent to compost houses and the small residue of waste is dumped into landfills with transportation costs borne by residents and profits from the waste bank.

Table 1. Comparison on Solid Waste Management in Research Locations

\begin{tabular}{|c|c|c|c|}
\hline Item & Rewin Village & Tin Village & Jambangan Depot \\
\hline $\begin{array}{l}\text { Waste } \\
\text { source }\end{array}$ & Domestic & Domestic & Domestic \\
\hline \multirow{5}{*}{$\begin{array}{l}\text { Waste bank } \\
\text { activities }\end{array}$} & Manage organic waste & Manage organic waste & Sorting waste \\
\hline & Saving for recreation & Saving \& Loan service & $\begin{array}{l}\text { Selling inorganic waste to } \\
\text { recycle factory }\end{array}$ \\
\hline & $\begin{array}{l}\text { Pay waste bank employee and } \\
\text { house of compost }\end{array}$ & Saving for recreation purposes & Selling second-hand goods \\
\hline & Making plastic handycraft & & $\begin{array}{l}\text { Giving bonuses for } \\
\text { employee }\end{array}$ \\
\hline & $\begin{array}{l}\text { Provid handycraft trainig for } \\
\text { society }\end{array}$ & & $\begin{array}{l}\text { Provide lunch and beverage } \\
\text { for employee }\end{array}$ \\
\hline \multirow[t]{2}{*}{$\begin{array}{l}\text { Organic } \\
\text { Waste }\end{array}$} & Composting in 'House of Compost' & $\begin{array}{l}\text { Composting using 'biopori' } \\
\text { technique ( } 1 \text { biopori hole for } 4 \\
\text { households) }\end{array}$ & Conventionl Composting \\
\hline & Planting trees & & Composting using larvae \\
\hline \multirow{2}{*}{$\begin{array}{l}\text { Inorganic } \\
\text { Waste }\end{array}$} & Collected to waste bank & Collected to waste bank & Sell to recycling company \\
\hline & & Sell to junkman directly & \\
\hline Residue & $\begin{array}{l}\text { Transported to landfill using group } \\
\text { leader private truck }\end{array}$ & $\begin{array}{l}\text { Transported to landfill by sanitary } \\
\text { agency car }\end{array}$ & $\begin{array}{l}\text { Transported to landifll } \\
\text { using agency truck }\end{array}$ \\
\hline \multirow{3}{*}{$\begin{array}{l}\text { Community } \\
\text { participation }\end{array}$} & Sorting waste & Sorting wastes & $\begin{array}{l}\text { Residents are not involved } \\
\text { in waste sorting }\end{array}$ \\
\hline & Using compost product for garden & Planting figs tree & \\
\hline & & Installing 'biopori' for composting & \\
\hline \multirow{2}{*}{$\begin{array}{l}\text { Business } \\
\text { pattern }\end{array}$} & Sell inorganic waste & Sell figs leaves tea & Sell second-hand goods \\
\hline & $\begin{array}{l}\text { Sell compost product for non- } \\
\text { member residents }\end{array}$ & $\begin{array}{l}\text { Sell figs fruit processing food } \\
\text { products }\end{array}$ & $\begin{array}{l}\text { Sell inorganic waste to } \\
\text { recycling company }\end{array}$ \\
\hline \multirow{4}{*}{$\begin{array}{l}\text { Community } \\
\text { development }\end{array}$} & $\begin{array}{l}\text { Waste separation and sorting } \\
\text { training }\end{array}$ & Figs tree planting training & $\begin{array}{l}\text { Information distribution via } \\
\text { sub-district to community } \\
\text { groups }\end{array}$ \\
\hline & $\begin{array}{l}\text { Waste bank trainig for group } \\
\text { leader, environmental leader, group } \\
\text { secretary }\end{array}$ & $\begin{array}{l}\text { Biopori technique composting } \\
\text { training }\end{array}$ & \\
\hline & & Waste bank management training & \\
\hline & & $\begin{array}{l}\text { Waste separation and sorting } \\
\text { training }\end{array}$ & \\
\hline \multirow{2}{*}{$\begin{array}{l}\text { Leader } \\
\text { effort }\end{array}$} & $\begin{array}{l}\text { Chairman of households group } \\
\text { invited residents to participate }\end{array}$ & $\begin{array}{l}\text { Chairman of households group } \\
\text { invited residents to participate }\end{array}$ & \\
\hline & $\begin{array}{l}\text { Environmental leader teach } \\
\text { residentas to sort waste }\end{array}$ & Visit residents to have discussions & \\
\hline \multirow[t]{2}{*}{$\begin{array}{l}\text { Waste } \\
\text { management } \\
\text { retribution }\end{array}$} & & & \\
\hline & IDR $13,000 /$ month & IDR $20,000 /$ month & IDR $25,000 /$ month \\
\hline
\end{tabular}




\section{Leader Efforts}

Community participation in reducing household solid waste, there are four strategies such as training in reducing HSW, disseminating information, increasing environmental cadres; and optimize the existence of waste banks and their functions. While the government / municipality has the role of providing counseling for the community so that they can manage their waste.

The recycling program has been carried out by various stakeholders including the government sector and private sector to reduce waste generation so that it is not thrown into the landfill. A policy review by the government is strongly recommended to identify factors that can influence more community participation in recycling programs.

Ineffective solid waste management remains a major challenge for many developing countries.

With this stakeholder-based SWOT analysis, efforts are made to explore ways and ways of turning 'threats' that might become 'opportunities' and turning 'weaknesses' into 'strengths' related to the community-based MSWM program.

In organizations that are concerned with reducing waste, reusing, and recycling projects of community waste, it provides a great opportunity to involve the community's role in the activities of the organization. They also have a significant impact on waste management, through service delivery and participation in related policy processes.

Organization only provides very simple services to improve sustainable waste management practices. Public sector to encourage them to manage their solid waste effectively, to reduce or even eliminate waste for landfill. There is a need to work towards a sustainable waste management system, which requires environmental sustainability.
A comprehensive approach that combines infrastructure improvement, health promotion, and community participation in the solid waste management process to increase inefficiencies to ensure quality sanitation. In Malaysia $70 \%$ of the actual amount of waste can be recycled or reused in certain ways. It become efforts to encourage, through education and awareness about managing solid waste to promote changes in attitudes and sustainable environmental practices must be done.

Community participation in waste management is the cheapest option and there is a strong case for involving community participation comprehensively in waste management.

The Ministry of Environment of Republic of Indonesia also issued Environment Ministry Regulation No. 13/2012, which sets guidelines for reducing, reusing, and recycling through solid waste banks. This regulation considers that MSW management does not currently apply the 3R concept and that solid waste management requires a comprehensive and integrated implementation. Therefore, it will provide economic benefits, improve public health, save the environment and change people's behavior.

The concept of Solid waste Management (SWM) is intended to reduce risks to public health. Therefore, the $3 \mathrm{R}$ approach is a guiding factor for SWM. But now, the United Nations Environment Program (UNEP) promotes the concept to cover all waste producing sectors to optimize recovery rates materials and resources for recycling and to improve the efficiency of waste management services. The ISWM concept is being changed to an ISWM system to replace the conventional SWM system.

Previous studies have suggested that community involvement and integration of waste recycling efforts into local MSW management may have a major influence on the implementation of waste reduction programs. 


\section{Conclusion}

The high level of education and income does not guarantee that a person participates in environmentally friendly activities. Every individual can do it as long as there is a will. Everyone can change with the influence of a leader who invites citizens to take part in protecting the environment and managing their solid waste. The participation of leaders and government action is very important in the success of a region. The invitation to play a role is very important; counseling from the government is very useful to be able to open people's minds, thus changing daily behavior and attitudes. The government's action to build a waste processing infrastructure, at a temporary disposal site is also very necessary, by sorting first, then organic waste is composted for city parks and the excess is for sale, then only the residue is transported to the landfill. Collaboration between the government and the community in managing solid waste in a sustainable manner will reduce the residue that is sent to the landfill, certainly has an impact on extending the life of the landfill.

\section{References}

Abdel-Fhafy, H.I., Mansour, M.S.M. (2018). Solid waste issue: Sources, composition, disposal, recycling, and volarization. Egyptian Journal of Petroleum, 27(4), 1275-1290.

Bonoli, A., Zanni, S., Awere, E. (2019). Organic waste composting and sustainability in low-income communities in Palestine: lesson from a pilot project in the village of Al Jalameh, Jenin. International Journal of Recycling of Organic Waste in Agriculture, 8, 253-262.

Fredrick, M., Oonyu, J.C., Sentongo, J. (2018). Influence of Education on the Solid Waste Management Practices of Communities in Kampala City. Journal of Environmental and Waste Management, 5(1), 261-274.

Hartono, J.M., Kristanto, G.A., Amin, S. (2015). Potential Reduction of Solid Waste
Generated From Traditional and Modern Markets, International Journal of Technology, 5, 838-846.

Hasbiah, A.W., Yustiani, Y.M., Desiriani, N.S. (2018). Composting Waste of Baglog Oyster Mushrooms Anaerobically with Variation of Activators, Goat and Urea Dirt in Cisarua Village, Lembang, West Bandung Regency. Proceeding of Community Development, 1, 205-215.

Kardono. (2008). Landfill Gas for Energy: Its Status and Prospect in Indonesia. J. Tek. Ling, 9(1), 1-8.

Nizar, M., Munir, E., Munawar, E., Irvan. (2018). Implementation of zero waste concept in waste management of Banda Aceh City. IOP Conference Series: Journal of Physics: Conf. Series, 1116, 052045.

Pan, I., Dam, B., Sen, S.K. (2012). Composting of common organic wastes using microbial inoculants. 3Biotech, 2(2), 127-134.

Rachman, I., Yustiani, Y.M., Raharjo, S., Deprida, D., Matsumoto, T. (2017). Analysis on the Appropriate Model of a Community-Based Waste Management (Case of Rural Area in Karang Joang Village, Balikpapan, Indonesia). Teknosia, 3(1), 32-39.

Raharjo, S., Matsumoto, T., Ihsan, T., Rachman, I., Gustin, L. (2017a). Community-based solid waste bank program for municipal solid waste management improvement in Indonesia: a case study of Padang city. Journal of Material Cycle and Waste Management, 19(1), 201-212.

Raharjo, S. Development of 3R waste treatment facilities for mitigating greenhouse gas emission: A case study of Padang city, Indonesia. ARPN Journal of Engineering and Applied Sciences, 12, 3789-3794.

Rijayanti, R., Thuy, T.T., Ou, Q. (2020). Community Participation in Waste Management in Changwon City, South Korea. Journal of Community Based Environmental Engineering and Management, 4(1), 37-44.

Solihin, M.M. (2018). Sustainable Waste Management trough Trash Bank in Ragajaya Village, Bogor Regency, West Java Province, Indonesia. International 
Journal of Progressive Sciences and Technology, 9(2), 190-198.

Yoada, R.M., Chirawurah, D., Adongo, P.B. (2014). Domestic waste disposal practice and perceptions of private sector waste management in urban Accra, BMC Public Health, 14:697.
Yustiani, Y.M., Rochaeni, A. (2019). Konsep Pengelolaan Sampah di Desa Babakan Kabupaten Bandung. EnviroScienteae, 15(1), 121-126.

Yustiani, Y.M., Abror, D.F. (2019). Operasional Bank Sampah Unit dalam Pengelolaan Sampah Perkotaan. Jurnalis, 2(2), 82-89 